ship with its requirement of compulsory military service to Japan, the United States, in event of war with Japan, could not demand military service from the Americanborn Japanese but would be obliged to permit them to return to Japan, there to render military service in behalf of Japan. American-born Japanese would appear to be enjoying all the advantages of American citizenship without assuming the most important responsibilities of such citizenship.

Once a Japanese always a Japanese, unless each individual Japanese renounced allegiance in the manner prescribed by the Civil Code of Japan and his renunciation is accepted by the Japanese Grovernment. No matter how many successive generations of American-born Japanese there may be, none of the children born in America are relieved of allegiance to Japan unless the parent has renounced allegiance to Japan and had his renunciation accepted by the Japanese Government.

While some of these points might be questioned, an important principle is touched upon in connection with the expatriation of the Japanese. On this point the report quotes from a letter of Dr. Charles E. Martin, Lecturer on International Law, University of California, dated March 25, 1920:

About 1917 or 1918 , the Japanese enacted a law of expatriation by which the status of dual nationality on the part of Japanese residing here and claiming citizenship under the Fourteenth Amendment could be brought to an end. Japanese who are native citizens of the United States may expatriate themselves in two ways:

(1) Before the age of 15 through a legal representative:

(2) Between the ages of 15 and 17 years, but never after the age of 17 , unless he has presented himself for military duty.

As compared with the practice of the United States, the Japanese law is limited in its scope. Japan will relinquish her jurisdiction over foreign-born Japanese, not through the voluntary act of the individual but only through the permission of the home government. Many countries hold to the view that expatriation is the voluntary right of the individual. Japan does not recognize this principle. The burden is placed upon foreign-born Americans to prove that they have retained their American citizenship, while the burden is placed upon foreign-born Japanese to prove that they have renounced their Japanese citizenship through means provided by, and with the permission of, the Japanese government. In this way, the home government has a rigid military hold on its foreign-born citizens.

In the Pacific Coast states the Japanese problem is becoming an increasingly serious one. No one state, or group of states, can hope to offer a sane solution for the problem because of the many international factors involved in the situation. The whole question must be handled by the states in coöperation with the federal government. In this direction only lies the hope for a constructive program.

\title{
The Japanese Question
}

\author{
By K. K. KawaKami ${ }^{1}$ \\ Author and Newspaper Correspondent, San Francisco, California
}

THE peace of the Pacific can not be maintained by a mutual policy of recrimination and discrimination

${ }^{1}$ Author of: Political Ideas of Modern Japan (1903), American-Japanese Relations (1912), Asia at the Door (1914), Japan in World Politics (1917), Japan and World Peace (1919). Also in Japanese History of Germany, Modern Socialism, Labor Question, Industrial Education.-The EDITOR. among the Powers bordering upon it. These Powers are at present represented by Japan in the East and by the United States in the West. The present attitude of fault-finding of each towards the other is fraught with danger, though it may not lead to an armed conflict. 
The function of an international peacemaker is to minimize and tolerate, though taking full cognizance of, those qualities of a people which differ from those of another.

The function of an international trouble-maker is to emphasize, exaggerate, and harp upon those qualities of a people which are dissimilar to those of another.

I put this direct question to sane and sober Americans: Shall America listen to the counsels of the peacemaker, or heed the clamors of the trouble-maker? Lpon the answer to this question, the peace of the Pacific must to no small extent depend.

No one denies that the Japanese are different from the Americans. Yet we believe that this difference is not so great as to create an insurmountable barrier against the Japanese. But for the sinister activities of proverbial busybodies and politicians and the yellow press, the Japanese in America can get along amicably with Americans.

Let me illustrate this with a few incidents which recently happened in California. A few weeks ago Japanese farmers at Calexico, in the Imperial Valley, were hosts to a number of American business men and their wives at a banquet at an American hotel. The vice president of the leading bank in Calexico, in behalf of the guests, thanked the Japanese in these words: "I wish to thank you for this invitation, and I am glad to be with you. If our Government is going to exclude Japanese from this country, it should also exclude all other undesirable elements of foreign nations."

The following day the Calexico post of the American legion, which tried hard to forestall the banquet, came out with violent denunciations of the Americans who accepted the Japanese hospitality.

Exactly the same incident happened in Lodi, a thriving farming town in Central California. A number of Japanese farmers and business men asked the leading Americans of the city to be their guests at a dinner. Among Americans present were the Mayor and the City Attorney of Lodi, the President of the Lodi Business Men's Association, and bankers and merchants. Upon the heels of this meeting came a resolution of the Lodi post of the American Legion, condemning the American participants in the banquet and declaring "that we look with disfavor and disapproval on any gathering intended to promote good fellowship and social affiliation between the Japanese and our own people."

If the Japanese in California are permitted to follow the natural course, if they are let alone by agitators and busybodies, they are capable of getting along harmoniously with the Americans. We see American workmen toiling side by side with Japanese on the rice fields and orchards, with no friction between them. We see American farmers employing Japanese, and Japanese farmers employing American laborers. In either case there is no trouble.

Even the prejudiced newspapers of California admit this to be a fact when they feel free to tell the truth. Shortly before the present recrudescence of agitation against the Japanese the Monterey Cypress had this to say: "It is a curious thing, and a sad commentary upon the attitude of the American employer towards labor, that American laborers will, by personal preference, enter the employ of a Japanese orchardist or rancher, when the same opportunity for employment is offered by American ranchers and orchardists."

The San José Mercury reports that "when there is a chance of getting 
work under a Japanese the men here make for it as fast as they can."

According to the Municipal Employment Bureau of San José the popularity of the Japanese farmers is due to the fact that they are, as a rule, considerate employers. As an American laborer, who applied to that bureau for a job, puts it, "the Japanese give their farm hands white sheets and treat them like white men."

It is but natural that the contact of two different races engenders a race feeling. As between the Japanese and Americans, however, that feeling, if not deliberately exploited by those with their own axes to grind, will create no such wide chasm as would baffle the ameliorating processes of Time and Nature, because their social disadvantage in the American community under normal condition has never been very great.

That this is not a mere assertion has been proved by California's calm attitude towards the Japanese after two years of continuous vitriolic agitation against them. For more than two years Senator Phelan and his political associates, with the solid backing of practically all the California press, have conducted a virulent propaganda against the Japanese, employing every imaginable means to incite racial antagonism. Mr. Hearst's powerful organs, supported by a large number of other papers, have given unlimited publicity to this anti-Japanese propaganda. Day after day, evening after evening, these papers published editorials and "editorialized" news items, all conceived to set the public sentiment against the Japanese. Many of these news items have proved to be barefaced falsehoods. Up and down the state the anti-Japanese forces held public meetings and conferences, whose proceedings and decisions were heralded far and wide by their newspaper allies. In a few interior towns they even put up sinister placards and posters announcing "No more Japanese wanted here" or "No Japanese employed here," which recalls to our minds "No Irish need apply," a sign seen in the eastern cities when Irish immigrants began to come to the Atlantic shores in large numbers.

To a student of social problems, the exploitation of the Japanese question by Pacific Coast newspapers is an interesting, often amusing, subject of study. When a paper comes out as a crusader against the Japanese, there are usually to be found sinister motives lurking behind the campaign. A few examples will suffice.

A daily journal, identified with organized labor, sells itself to capital in a strike. The strike fails, and capital has no more use for the "yellow sheet." Deserted by capital and scorned by labor which it has betrayed, the paper finds itself between the devil and the deep sea. Soon it starts a spectacular propaganda against the Japanese, thus hoping to regain labor's favor.

Another newspaper tries to extort a handsome sum of money from a Japanese community. The Japanese reject the advance. Soon afterward the paper embarks upon a campaign of defamation against the Japanese.

As with newspapers, so with individuals. A Japanese buys a city home from a real estate agent; whereupon another agent, who failed to make a deal with the Japanese, bestirs himself and spreads the evil tidings of a "Japanese invasion" throughout the city.

Again, two rival agents try to sell a farm to a Japanese. The Japanese deals with one agent, whose offer is more reasonable, and the other disgruntled agent sends for the leaders of an anti-Japanese organization and 
holds a mass meeting to stir up animosity towards all Japanese in the village.

When I recall such stories, of which I can write a volume, I am almost inclined to lose faith in the goodness of human nature. Surely, you will begin to think that after all America is not an apotheosis of justice and humanity.

As for the motives of anti-Japanese politicians, I shall confine myself to quoting no less an authority than Governor William D. Stephens of California. He said in January last: "In my opinion the present agitation in California was inspired by candidacy for office. It is true that many worthy citizens have now allied themselves with it with a laudable purpose. The fact remains, however, that the dominant factors in the movement are actuated by their desires for political preferment."

The statement was lengthy and minced no words in admonishing various political aspirants. And yet the same governor made public, on the eve of the Democratic Convention in San Francisco, a lengthy letter addressed to Secretary of State Colby, in which he practically endorsed most of the anti-Japanese program advocated by those politicians whom he had scolded for playing politics. The astute governor did this, not because he had changed his mind, but because the agitation by Senator Phelan and others created an atmosphere in which no politician felt safe in maintaining an attitude liable to be interpreted as pro-Japanese. In the parlance of the political world, the governor's move was a move to steal Mr. Phelan's thunder.

But let us ignore the motive. For our present purpose, it is enough to see only the obvious, and note, as I have noted, how vicious, how vitriolic, the anti-Japanese propaganda has been. Of late this propaganda has been reënforced by moving pictures and novels, evidently inspired by leaders of anti-Japanese agitation. One newspaper is publishing a serial, an undisguised anti-Japanese propaganda novel, written by a GermanAmerican who was arrested and interned at Fort Douglas during the war for his anti-American activities.

The important point, which I wish to drive home to the public, is that, in spite of all this propaganda, the average Californian shows little disposition to be excited or alarmed by the bogie of the Japanese menace conjured up by agitators. No Japanese has suffered physical attack at the hands of "hoodlums." No property owned by Japanese has been destroyed by the "riff-raff" elements. Only once or twice yellow journals have reported alleged cases of rough treatment meted out to the Japanese, but upon investigation such reports have proved groundless and nothing but the usual trick of newspapers to incite animosity against the Japanese. Everywhere the Japanese are getting along amicably with the Americans. Japanese are employing and being employed by Americans. Americans are glad to employ, and work for, Japanese. In cafés and restaurants, at hotels and theatres, there is no disposition to even discriminate against the Japanese. Senator Phelan is right in objecting to the use of the word "pogrom" used by an ardent defender of the Japanese, for there never has been even a hint of pogrom in the attitude of the Californians towards the Japanese.

The failure of anti-Japanese propagandists to incite race hatred against the Japanese proves two things. First, the Japanese have the innate capacity to live harmoniously side by side with Americans. Second, with the growth of Japanese immigration effectively 
checked by federal arrangements, the present Japanese population and Japanese land holdings constitute no real menace. To make them appear a menace by a campaign of exaggeration and falsehood is an affront to the intelligence of the American people. Says the American Committee of Justice, organized in California to oppose the recently adopted Alien Land Initiative Law: "Only 2.2 per cent of California's total population is Japanese. In 1919 more white children were born in California than all the Japanese children born here in the ten years preceding. We should not be placed in the ridiculous position of 97.8 per cent of our population being in fear of 2.2 per cent. We would be confessing ourselves weaklings and fools if we were to think that our institutions and civilization are being endangered by the presence of such a small number of Japanese, unobtrusive, law-abiding, minding their own business, and bothering nobody. The State Board of Control reports that Japanese cultivated 458,056 acres last year. California has an area of $99,617,280$ acres of which about $28,000,000$ is farm land. Of this vast farm land only 1.6 per cent is cultivated by Japanese. Upon this 1.6 per cent they produce 13 per cent of California's total food output. Their produce is valued at sixty-seven million dollars, of which 35 per cent is paid land owners as rentals and 45 per cent to labor as wages. The balance of 20 per cent is the reward for Japanese tenants and contractors. The Japanese have taken up much of the worst land and made it fertile, thus helping to reduce the cost of food for the city worker. With effective restriction of Japanese immigration now being considered at Washington, there need be no fear that the small Japanese population now here will ever become a dominating element.
The present Japanese population is only 2.2 per cent of the total. The highest Japanese birth-rate is only 7.4 per cent of the whole as against 90.8 per cent of American births. Within a few years Japanese births will become even less, because (1) immigrants, irrespective of race, have fewer children after the first generation; (2) the average age of Japanese male adults now here is about 40 ; (3) the abolition of 'picture marriages' will make it more difficult for Japanese to marry; (4) the arrivals of Japanese will decrease as the result of present diplomatic negotiations."

This complacent attitude on the part of Californians has been proven by the result of the recent election. Senator Phelan, the apostle of antiJapanism, has given way to his Republican opponent by a difference of 70,000 votes. The majority for the Alien Land Initiative Law has been disappointingly small for the anti-Japanese leaders. On the eve of the election, it was generally predicted, by both the Japanese and the Americans, that the Initiative would be adopted by a majority of 9 to 1 . But the returns, though yet incomplete, have revealed a remarkable pro-Japanese sentiment, latent or potential in the hearts of the Californians. Up to date 5,586 electoral precincts out of a total of some 6,000 have made returns on the vote. These returns show 608,000 votes for the anti-Japanese law, and 230,000 against it. The majority is less than 3 to 1 .

This is all the more remarkable when we consider that, during the past two years, the Japanese were given no hearing at all in the columns of any newspaper. The avenue of publicity was completely closed to them. We had no organization of Americans to assist us. We were powerless and helpless. We made no 
attempt to present our side before the public, for we knew that such attempts were futile. It was only during the few weeks immediately preceding the election that the Japanese Association sent out a few documents, giving authentic facts on the question and that a number of sympathetic Americans began to realize the seriousness of the situation, and with no solicitation from the Japanese, came to their assistance. In the face of the complete monopoly of the public ear by the other side, we are justified in stating that the recent vote has proven that the sentiment in California is far from entirely against the Japanese. We must remember that California's voters number $1,360,000$, of which about 400,000 did not vote. Many, perhaps a majority, of those who failed to vote were decent, intelligent, fair-minded people, who were disgusted with politics and politicians and took to the golf links or went motoring on the election day. Had these people exercised their franchise, the proportion of votes for and against the Initiative would have been more favorable to the Japanese.

Some Americans point to Hawaii as an example of the Orientalization of a white man's land, and sound warning against the Hawaiianization of California. With due respect to their intelligence, I am constrained to say that these Americans would render their country a better service if they would tell the truth about the American annexation of Hawaii. In the light of authentic history that annexation is far less justifiable than the Japanese annexation of Korea. It indeed had no justification whatever, except that American interests wanted the islands. But there is no use in discussing history here. The point is that the growth of the Hawaiian population is unique and abnormal, and can not serve as a basis of forecast for any state on the continent.

To begin with, Hawaii was not a white man's land. Years before the American annexation of the islands, American capitalists went there to develop sugar plantations. As the islands were too far from the continent, and as their climate was too hot, these plantation operators could not get American labor, but relied upon labor brought from the Orient. So they brought Japanese laborers by the shipload. From the beginning these Americans never intended Hawaii to be a white man's land; they plainly intended it to be a land of the natives and Orientals. When America finally annexed it, practically in 1893 , formally in 1897 , she inherited the conditions that had already been established by ceaseless importation of Oriental labor by a handful of Americans who had been there to develop its sugar resources. Had America been in a position to apply to Hawaii the same restrictive measure that she has applied to continental United States, Hawaii would have had an entirely different sort of population.

To argue from Hawaii to California is illogical. Here in California the American population, since Chinese exclusion, has always been preponderant, and promises to be increasingly so. Today the Japanese population here constitutes only 2 per cent of the total population. With steady inflow of Caucasian population from across the Rockies, and with the increasing Caucasian births within the state, California has not the slightest chance of ever becoming a second Hawaii.

A significant fact in the present agitation against the Japanese is organized labor's apathy towards it. At the time of the San Francisco school incident of fifteen years ago, organized labor was the motive power 
of agitation. In the movement leading to the enactment of the anti-Japanese land law of 1913, organized labor played the most prominent part. But in the present movement labor has been a follower, not a leader.

In August last the Labor Council of Stockton, the city near which George Shima, the Japanese "potato king," has extensive farms, adopted these recommendations:

"1. $\Lambda$ bsolute restriction of all alien immigration;

2. No fight to be made upon any person or persons who are legal residents of the United States;

3. Organize all workers who are capable of taking a union man's job;

4. We do not favor the removal of the Oriental from land to the industries."

A similar resolution was adopted by the Federated Trades Council of Sacramento, the city regarded as the hotbed of anti-Japanese agitation. In view of what trade-unions had said and done on the Japanese question, these resolutions seem almost increditable, but they were passed almost unanimously in Stockton and Sacramento.

This modification of attitude on the part of organized labor is mainly due to the fact that the Japanese no longer compete with American labor. The Japanese farmhands and domestic laborers are getting as much as, and in some cases even more than, their American fellows. Moreover, in the past sereral years Japanese farmers have become employers of American labor. Thus American laborers have come to know that the Japanese are considerate and generous employers.

Another significant point is the difference of California's attitude towards the Chinese up to a score of years ago from that towards the Japanese today. As we have noted there is no bitter race antagonism towards the Japanese. This certainly could not be said with regard to California's treatment of the Chinese from 1860 to 1890.

In 1862 the Chinese Six Companies reported to the California Senate that 88 Chinese had been murdered, 11 of them by tax collectors, but the report received no attention. In 1867,30 Chinese employed in grading in San Francisco were violently attacked by a mob, and were seriously injured. In those days it was a common sight in San Francisco and other cities to see Chinese pelted with stones or mud, beaten or kicked, having vegetables or laundry stolen from their baskets and even having their queues cut. On one occasion 150 Chinese, landing from the Sacramento boat in San Francisco, were ruthlessly beaten and robbed.

In July, 1877, the storm of violence broke over the whole city of San Francisco. At the first flash of riots twentyfive wash houses were set on fire. This was followed by an orgy of outrages. For months no Chinese was safe from physical assaults. An epidemic of arson and robbery swept the city and the surrounding country. In many towns Chinese laundries were subjected to incendiarism. If the Chinese attempted to escape from burning houses, they were invariably beaten and kicked, often robbed and shot, and sometimes compelled to die in the flames. The Chinese could no longer attend safely the mission schools in the cities. Many were obliged to seek refuge in the mountains and in the remote country districts. The crowning outrage was perpetrated in Truckee in November, 1878, when the entire Chinese population of 1,000 persons was ruthlessly driven out of the town.

What California said about the Chinese was as vicious as the physical injuries which she inflicted upon them. 
The utterances used were so vile that we are ashamed to reproduce them here. California may congratulate herself that she has spoken no such language about the Japanese.

It has been the tactics of the advocates of the Alien Land Law to create the impression that Japan herself does not allow foreigners to own or lease land. As a conclusive evidence that foreign residents in Japan do own and lease land, I present the following figures:

1. 169 corporations, organized exclusively by foreigners, own 656 acres, of which about 164 acres are farm lands.

2. 69 foreign individuals, including 20 Americans, own, in the names of Japanese, 195 acres, of which 18 acres are farm lands.

3. 336 foreigners, including 55 Americans, hold perpetual leases on 430 acres of city lots.

4. 335 foreigners, including 100 Americans, hold superficies on 547 acres of land of which 52 acres are farm lands, the balance being city lots, forests, pastures, etc.

True, these figures show that foreign, and especially American, holdings in Japan are very small. But this is due, not to the impediment of the law, but to the scarcity of available land, and the consequent high price of real property.

Under Japan's existing laws, foreigners as individuals can not own land, but corporations organized by aliens in compliance with the provisions of the Japanese Commercial Code can own land. Again the Civil Code of Japan allows aliens to lease land of any description for fifty years, and to hold the right of superficies for unlimited periods. Furthermore, foreigners in Japan still enjoy the benefit of perpetual lease, a peculiar prerogative established in the days of exterritoriality.

Everyone realizes that the contact of different peoples and civilizations is liable to create friction. The simplest way to avoid this friction would be to build a Chinese wall around each country, and return to the "blessed" isolation of many centuries ago. But it is now idle to talk of such a plan. The unalterable fact is that the West has gone to the East, and the East has come to the West. And, be it remembered, it was the Western gun which forced open the doors of the East. The only sensible and honorable course the East and West can now follow is a course of mutual concession, of mutual tolerance, of "live and let live." Unless Japan and America are willing to pursue this course, the peace of the Pacific can not be maintained.

\section{Is the Japanese Menace in America a Reality?}

\section{By KiIChi Kanzaki}

General Secretary, The Japanese Association of America, San Francisco

\section{$I^{N}$} recent years, and particularly during the past twelve months, a very great deal has been said concerning a Japanese menace in America. Does such a menace in fact exist? To find the answer to this question will be the object of the discussion that is to follow.

First of all, it must be fully recognized that there is a real distinction between the Japanese question in the Far East and the Japanese question in 